\title{
Determination of Groundwater Potentials in Crystalline Basement Areas of Bauchi Local Government Area, Bauchi
}

\author{
ES Abimiku $^{1 *} \quad$ A Dadan-Garba ${ }^{2} \quad$ AA Adepetu ${ }^{3}$ \\ 1.Department of Geography, Federal University, Gashua, Yobe State Nigeria \\ 2.Department of Geography, Nigerian Defense Academy, Kaduna, Kaduna State, Nigeria \\ 3.Department of Geography, Kaduna State University, Kaduna, Kaduna State, Nigeria \\ Corresponding address, email and telephone number: \\ Department of Geography, Federal University, Gashua, \\ Yobe State Nigeria
}

\begin{abstract}
Developing groundwater is generally an excellent option for sustainable water supplies in Bauchi due to the ephemeral nature of surface water. However, the large variability in geological and hydrological conditions have a profound influence on the availability of groundwater across the study area. The rationale for this research is to contribute at least, in terms of providing empirical data towards sustainable development of groundwater resource, particularly in the Crystalline Basement hydrogeological unit of Bauchi area. Aquifer properties of wells within the Crystalline Basement were estimated from a constant-rate pumping test of 10 sampled wells by fitting mathematical models (type curves) to drawdown data through curve matching. Generally, yields of sampled boreholes within the crystalline basement aquifer range from $8.64 \mathrm{~m}^{3} / \mathrm{d}$ to $120.96 \mathrm{~m}^{3} / \mathrm{d}$ with an average of 52.36 $\mathrm{m}^{3} / \mathrm{d}$. The total yield of the boreholes is about $661.83 . \mathrm{m}^{3} /$ day. This can sustain a population of 26,473 based on water supply standard of 25 litres per day for rural communities (Babatola, 1997). Considering the total population of 12,218 people (NPC, 2014) that are currently using the water points in comparison to water supply standard of 25 litre per person per day, this shows that the aquifers from the 10 sampled boreholes have relatively enough groundwater in terms of yield to meet the water need of the population. However, any significant increase in population growth may result in water scarcity in these areas, as the Crystalline Basement aquifers generally have low yielding capacity. Also, the crystalline basement aquifer properties evaluated reveal that the transmissivity values range from $2.55 \mathrm{~m}^{2} /$ day to $111.0 \mathrm{~m}^{2}$ /day with an average of $38.94 \mathrm{~m}^{2} /$ day (Table 5 ). According to Offodile (2002), a transmissivity range of 5 to $50 \mathrm{~m}^{2} /$ day could be regarded as high potential in crystalline rock situations. By the above standard, the crystalline basement aquifers in the area are classified as aquifers of negligible to high potentials. The specific capacities of boreholes in the study area were computed and the results show that they vary between 1.30 to $691.2 \mathrm{~m}^{2} / \mathrm{d} / \mathrm{m}$.
\end{abstract}

Keywords: Crystalline Basement, Groundwater, Pumping Test, Aquifer, Transmissivity, Bauchi State, Nigeria DOI: $10.7176 / \mathrm{JEES} / 9-7-02$

Publication date:July $31^{\text {st }} 2019$

\section{Introduction}

The distribution of water on the Earth's surface is extremely uneven. About one-third of the world's population lives in countries suffering from moderate-to-high water stress, where water consumption is more than 10 per cent of renewable freshwater resources (UNESCO, 2016). About 2 billion people, approximately one-third of the world's population, depend on groundwater supplies, withdrawing about 20 per cent of global water (600-700 km3) annually, much of it from shallow aquifers (UNEP, 2002).

The Nigerian Geological set up comprises broadly, of sedimentary formations and crystalline rocks of the Basement complex type. The Basement complex are thought to be Precambrian., mainly granitic in composition, and in different stages of metamorphism, either as gneisses, migmatites, schists, phyllites and or quartzites (Offodile, 2014). There are Older and Younger granites, the latter being confined mainly to the Jos Plateau region and some parts of the mid lower region of Niger State of Nigeria. The Older granite rocks are hard, with low permeability, and generally not water bearing. They cover parts of Bauchi, Kano, Kwara and Kaduna (Offodile, 2014).

The area of the country covered by the Basement complex is considerable and most of these falls within the semi-arid parts of the country where surface water is either seasonal and sometimes non-existent, and groundwater would then be the only source of water. The groundwater storage which is already limited by geological factors is further reduced by adverse climatic conditions. In the northern and the semi-arid climatic regions of the country, which also include the study area of this research, almost entirely underlain by crystalline rock formations (See Figure 1), groundwater and surface water are scarce and problematic. Hence, despite its poor hydrogeological characteristics, the Basement Complex is still very important in groundwater development in Nigeria (Offodile, 2014). 


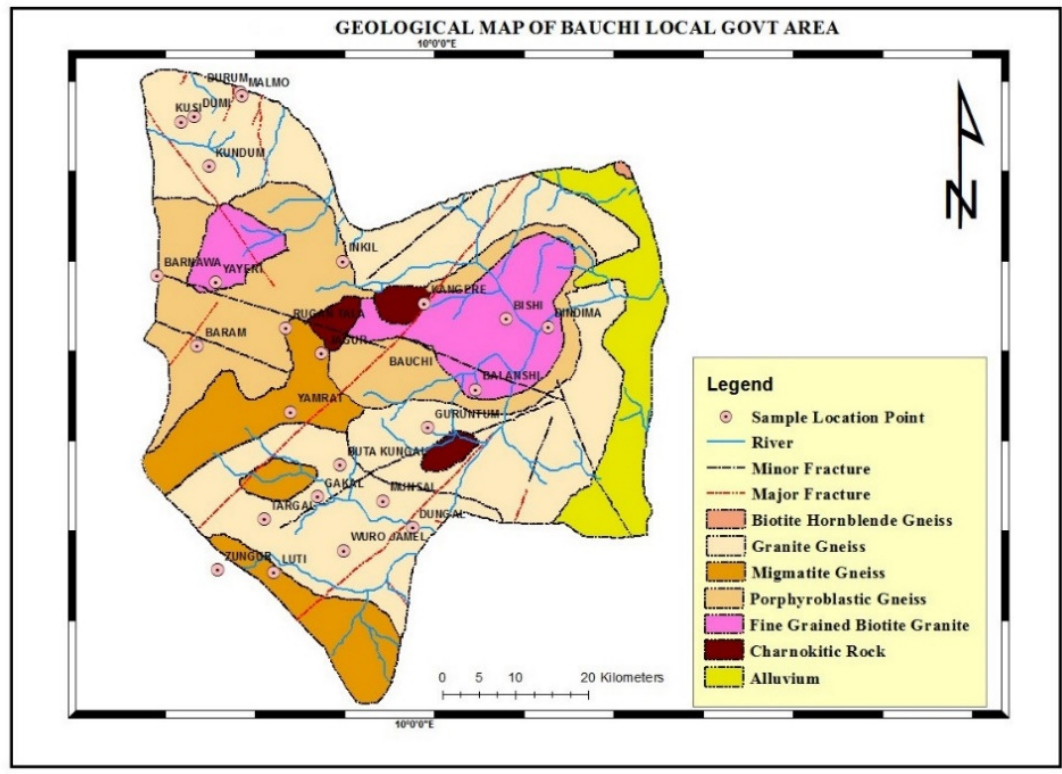

Figure 1: The Geology of Bauchi Local Government Area

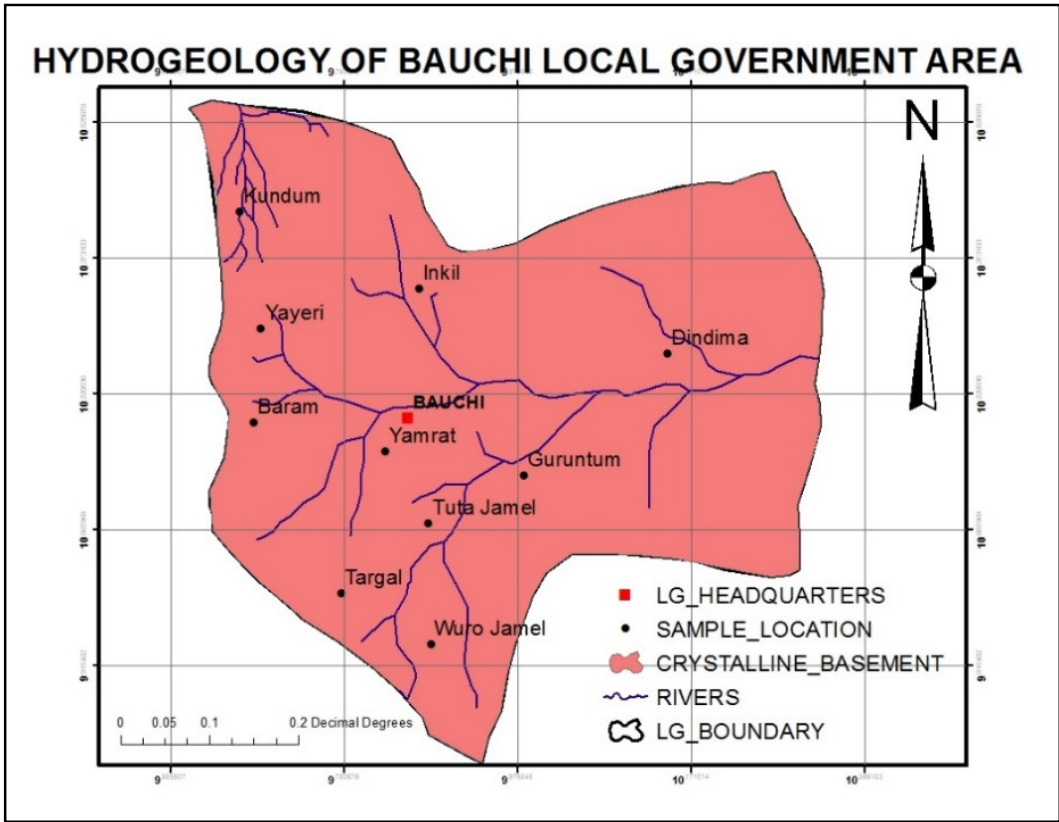

Figure 2: The Hydrogeology of Bauchi Local Government Area

According to Chow, Maidment, and Mays, (1988), groundwater is the water beneath the ground surface contained in void spaces (pore spaces between rock and soil particles, or bedrock fractures). Vincent et al, (2009) stated that groundwater occurs in unconsolidated and consolidated bedrock geologic formations. In unconsolidated formations, which are made up of porous media (gravels, sands, silts and clays), the groundwater is stored and travels in the pore spaces between the particles. In bedrock formations, the water is stored and travels in joints, fissures and fractures in the rock, referred to as secondary porosity.

Crystalline Rock is a solid, dense rock where groundwater is stored in joints, crevices, and cracks. Crystalline basement rocks are present over large parts of Africa and Asia. They comprise ancient igneous and metamorphic rocks over 550 million years old. Unweathered basement rock contains negligible groundwater, but significant aquifers develop within the weathered over- bedrock (Wright and Burgess 1992).

The water bearing zones in the Crystalline Basement hydrogeological unit (See Figure 2) occurs either in fractures of poorly decomposed rock, intergranular permeability in moderately decomposed coarse grained igneous and metamorphic rock as well as fractured pegmatite, aplite and quartz veins within highly and moderately decomposed gneisses and migmatite (BSADP, 1988). Within the weathered zone, discontinuous water table aquifer occurs in which the water level shows marked seasonal fluctuation due to the low permeability of the 
weathered material (BSADP, 1988).

Also, previous assessment on the hydrogeological properties of the basement aquifer of Bauchi state by Shemang and Jiba (2005) identified two basic types of aquifers in the area, fractured crystalline rocks and weathered crystalline rocks that overlie the former. The search for groundwater in these regions therefore requires good understanding of the hydrogeology of the area. In view of this, this study is set to determine the groundwater potentials of Crystalline Basement aquifer of Bauchi area. This is with the hope that the results of the investigation will be useful to government, policy makers and other stakeholders in designing appropriate rural water supply schemes.

\section{Materials and Methods}

Pumping test was conducted on ten boreholes within the study area, while the lithology logs of the ten boreholes where obtained from Rural Water and Sanitation Agency (RUWASA). Information on the geological and hydrogeology of Bauchi State were obtained from available maps from Bauchi State Agricultural Development Project (BSADP). BSADP defined five hydrogeological units in the state that present fundamental differences in their lithologic and structural conformation (BSADP, 1988). However, this particular study focuses only on the Crystalline Basement.

The logs enabled the establishment of the subsurface stratification, casing and screen positions, static water levels and aquifer textural properties while the aquifer pumping test data for each borehole comprised 3 to 4 stage step-drawdown tests, single stage and recovery measurements. These were used to determine aquifer hydraulic properties such as transmissivity (T), hydraulic conductivity (K) and specific capacity (Cs). Pumping test data analysis was based on the Cooper-Jacob's (1946) non-equilibrium graphical method. This method has been found suitable where the abstraction well itself serves as the observation well, as is the case in the present study. By this method, the transmissivity $(\mathrm{T})$ is given by:

$\mathrm{T}=\frac{2.303 \mathrm{Q}}{4 \Pi \Delta \mathrm{S}} \cdots \cdots(1)$

Where $\mathrm{Q}=$ discharge or yield $\left(\mathrm{m}^{3} / \mathrm{sec}\right)$.

$\Delta \mathrm{S}=$ change in drawdown over one log cycle.

This formula is useful because some of the boreholes are confined while others are semi-confined. The average drawdown for the ten boreholes is about $17.25 \mathrm{~m}$. The hydraulic conductivity $(\mathrm{K})$ was calculated from

$$
\mathrm{K}=\frac{\mathrm{T}}{\mathrm{b}}
$$

Where $\mathrm{T}=$ as in (1) above

$\mathrm{B}=$ aquifer thickness (equivalent to the total screen length).

The specific capacity (Cs), a measure of well productivity, was computed from:

$$
\mathrm{Cs}=\frac{\mathrm{Q}}{\mathrm{S}}
$$

Where $\mathrm{Q}=$ as in (1) above

$\mathrm{S}=$ maximum drawdown

\section{Results and Discussions}

The Crystalline Basement hydrogeological unit lies entirely within the Crystalline Basement terrain (See Figure 1). The formations penetrated were mainly migmatites and gneisses which are cut by pegmatite, aplite and quartz veins and weathered to varying depths. The water bearing zones are: fractures in the poorly decomposed rock; intergranular permeability in moderately decomposed coarse grained igneous and metamorphic rocks and fractured pegmatite, aplite and quartz veins within highly and moderately decomposed gneisses and migmatites. The probability of obtaining a high-yield well in crystalline rock areas can be maximized if drilling takes place in an area where fractures are localized.

Boreholes yield are generally low, most in the range of 7.78 to $120.96 \mathrm{~m}^{3} / \mathrm{d}$ with an average of $52.36 \mathrm{~m}^{3} / \mathrm{d}$. Boreholes at Kundum and Yamrat produce $7.78 \mathrm{~m}^{3} / \mathrm{d}$ and $8.64 \mathrm{~m}^{3} / \mathrm{d}$ respectively, barely not even sufficient for a handpump. Five were rated as capable of producing over $100 \mathrm{~m}^{3} / \mathrm{d}$, six of which were rated at less than $100 \mathrm{~m}^{3} / \mathrm{d}$. The total yield of the boreholes is about $661.83 . \mathrm{m}^{3} /$ day. This can sustain a population of 26,473 based on water supply standard of 25 litres per day for rural communities (Babatola, 1997). Considering the total population of 12,218 people (NPC 2014 ) that are currently using the water points in comparison to water supply standard of 25 litre per person per day, this shows that the aquifers from the 10 sampled boreholes have relatively enough groundwater in terms of yield to meet the water need of the population. However, any significant increase in population growth may result in water scarcity in these areas, as the Crystalline Basement aquifers generally have low yielding capacity. 
Hazell et al, (1992) described the hydrogeological conditions found in Bauchi town and its surrounding. He concluded that water is found in the superficial weathered mantle derived from the crystalline rocks of basement complex which form an aquifer of poor quality. The drawdown in the boreholes vary greatly from as low as 2.9 to as greater as 38.6 metres. Measurement from boreholes show that the static water table is generally shallow and ranges from $3.1 \mathrm{~m}$ to about $5.9 \mathrm{~m}$. The static water level is at an average depth of $4.3 \mathrm{~m}$ (See Table 1).

Also, the crystalline basement aquifer properties evaluated reveal that the transmissivity values range from $2.55 \mathrm{~m}^{2} /$ day to $111.0 \mathrm{~m}^{2} /$ day with an average of $38.94 \mathrm{~m}^{2} /$ day (Table 1). According to Offodile (2002), a transmissivity range of 5 to $50 \mathrm{~m}^{2}$ /day could be regarded as high potential in crystalline rock situations. By the above standard, the crystalline basement aquifers in the area are classified as aquifers of negligible to high potentials. The specific capacities of boreholes in the study area were computed and the results show that they vary between 1.30 to $691.2 \mathrm{~m}^{2} / \mathrm{d} / \mathrm{m}$. Seventy percent (70\%) of the boreholes have specific capacities between 50 and $691.2 \mathrm{~m}^{2} / \mathrm{d} / \mathrm{m}$, suggesting that transmissivities of those boreholes are high. Hydraulic conductivity was obtained for ten (10) selected boreholes in the study area and the results are shown in Table 1. The conductivity varied from aquifer to aquifer and range generally from as low as 0.094 to about $6.12 \mathrm{~m} /$ day.

Table 1: Hydraulic Characteristics of Boreholes from Crystalline Basement Hydrogeological Unit

\begin{tabular}{|c|c|c|c|c|c|c|c|c|c|c|c|c|}
\hline $\begin{array}{c}\mathrm{S} / \\
\text { No }\end{array}$ & $\begin{array}{l}\text { Locati } \\
\text { on }\end{array}$ & $\begin{array}{l}\text { De } \\
\text { pth } \\
\text { (m) }\end{array}$ & $\begin{array}{c}\text { Scre } \\
\text { en } \\
\text { Inter } \\
\text { val }\end{array}$ & $\begin{array}{c}\text { Aquif } \\
\text { er } \\
\text { Thick } \\
\text { ness } \\
\text { (m) }\end{array}$ & $\begin{array}{c}\text { Stat } \\
\text { ic } \\
\text { Wa } \\
\text { ter } \\
\text { Lev } \\
\text { el } \\
\text { (m) }\end{array}$ & $\begin{array}{c}\text { Dyna } \\
\text { mic } \\
\text { Wate } \\
r \\
\text { Level } \\
\text { (m) }\end{array}$ & $\begin{array}{c}\text { Drawd } \\
\text { own } \\
\text { m }\end{array}$ & $\begin{array}{c}\text { Est. } \\
\text { Yiel } \\
d \\
\left(\mathrm{~m}^{3} /\right. \\
\mathrm{d})\end{array}$ & $\begin{array}{c}\text { Transmi } \\
\text { sivity } \\
\mathrm{m}^{2} / \mathrm{d}\end{array}$ & $\begin{array}{c}\text { Hydraul } \\
\text { ic } \\
\text { Conduct } \\
\text { ivity } \\
\text { m/day }\end{array}$ & $\begin{array}{c}\text { Speci } \\
\text { fic } \\
\text { Capa } \\
\text { city } \\
\mathrm{m}^{2} / \mathrm{d} / \\
\mathrm{m}\end{array}$ & $\begin{array}{c}\text { Storati } \\
\text { vity }\end{array}$ \\
\hline 1 & Baram & $\begin{array}{c}26 . \\
2\end{array}$ & $\begin{array}{c}20.0 \\
- \\
26.2\end{array}$ & 6.2 & 3.2 & 6.6 & 3.4 & $\begin{array}{c}103 . \\
68\end{array}$ & 9.49 & 0.43 & 119 & 5.42 \\
\hline 2 & $\begin{array}{l}\text { Yayer } \\
\text { i }\end{array}$ & $\begin{array}{c}26 . \\
4\end{array}$ & $\begin{array}{l}9.0- \\
17.0\end{array}$ & 8 & 4.3 & 24.4 & 20.1 & $\begin{array}{c}34.5 \\
6\end{array}$ & 52 & 2.39 & 691.2 & 31.34 \\
\hline 3 & Targal & $\begin{array}{c}26 . \\
4\end{array}$ & $\begin{array}{c}19.5 \\
- \\
26.4 \\
\end{array}$ & 6.9 & 4.3 & 24.4 & 20.1 & $\begin{array}{l}34.5 \\
6\end{array}$ & 52 & 2.39 & 691.2 & 1.57 \\
\hline 4 & $\begin{array}{l}\text { Wuro } \\
\text { Jamel }\end{array}$ & $\begin{array}{c}44 . \\
3\end{array}$ & $\begin{array}{c}27.0 \\
- \\
32.0 \\
\end{array}$ & 5 & 4.5 & 42.5 & 38 & $\begin{array}{c}30.2 \\
4\end{array}$ & 111 & 6.12 & 1.39 & 0.07 \\
\hline 5 & $\begin{array}{l}\text { Kund } \\
\text { um }\end{array}$ & $\begin{array}{c}38 . \\
2\end{array}$ & $\begin{array}{c}25.0 \\
- \\
31.0\end{array}$ & 6 & 4.9 & 36.3 & 31.4 & 7.78 & 6.47 & 0.19 & 86.3 & 2.48 \\
\hline 6 & $\begin{array}{l}\text { Dindi } \\
\text { ma }\end{array}$ & $\begin{array}{c}28 . \\
5\end{array}$ & $\begin{array}{c}15.0 \\
- \\
25.0\end{array}$ & 10 & 5.9 & 9.5 & 3.6 & $\begin{array}{c}105 . \\
41\end{array}$ & 23.24 & 1.04 & 293 & 13.17 \\
\hline 7 & \begin{tabular}{|l|} 
Buta \\
Kunga \\
1 \\
\end{tabular} & $\begin{array}{c}37 . \\
7\end{array}$ & $\begin{array}{c}28.0 \\
- \\
36.0 \\
\end{array}$ & 8 & 5.0 & 13.5 & 8.5 & $\begin{array}{c}103 . \\
68\end{array}$ & 100.2 & 3.12 & 1.30 & 0.04 \\
\hline 8 & Inkil & $\begin{array}{c}49 . \\
5\end{array}$ & $\begin{array}{c}32.0 \\
- \\
43.0 \\
\end{array}$ & 11 & 4.4 & 10.3 & 5.9 & $\begin{array}{c}120 . \\
96\end{array}$ & 19.47 & 0.43 & 247 & 2.71 \\
\hline 9 & $\begin{array}{l}\text { Yamr } \\
\text { at }\end{array}$ & 34 & $\begin{array}{c}21.0 \\
- \\
32.0 \\
\end{array}$ & 11 & 3.5 & 6.4 & 2.9 & $\begin{array}{c}112 . \\
32\end{array}$ & 2.55 & 0.094 & 32 & 4.16 \\
\hline 10 & $\begin{array}{l}\text { Gurun } \\
\text { tum }\end{array}$ & $\begin{array}{c}53 . \\
0\end{array}$ & $\begin{array}{c}41.0 \\
- \\
52.0\end{array}$ & 11 & 3.1 & 43.7 & 38.6 & 8.64 & 13 & 0.26 & 172.8 & 0.17 \\
\hline & $\begin{array}{c}\text { Avera } \\
\text { ge }\end{array}$ & $\begin{array}{l}36 . \\
42 \\
\end{array}$ & & 8.31 & 4.3 & 21.76 & 17.25 & $\begin{array}{c}52.3 \\
6 \\
\end{array}$ & 38.94 & 1.65 & $\begin{array}{c}233.5 \\
2 \\
\end{array}$ & 6.11 \\
\hline
\end{tabular}

\section{Conclusion}

The study provide data on availability and potentials of groundwater systems in Crystalline Basement hydrogeological unit of Bauchi State. Data on aquifer characteristics such as yield, water table, borehole depth, transmissivity, and specific capacity were obtained through measurement and pumping test analysis of 10 sampled 
boreholes in the study area. Analysis of hydraulic characteristics of aquifer systems in the area shows that considerable potions of Bauchi state falls under Crystalline Basement hydrogeological unit. The study reveals that groundwater occurrence in the Crystalline Basement were structurally controlled (i.e. aquifers occurred in joints and fault zones), and also in weathered zones. The fractured zone aquifers were mostly confined or semi confined and contained relatively moderate yielding capacities as observed in the estimated transmissivity.

\section{References}

Babatola, J. O. (1997). Rural Water Supply: Issues, Problems and Prospects. Water Resources Journal of NAH, 8 (1), 19-25.

Bauchi State Agriculture Development Project. (1988). Bauchi State Hydrogeology Hydrogeological Unit Descriptions by Wardrop Engineering Inc. Winnipeg, Canada, based on 1205 boreholes and 234 boreholes constructed under Contract BSADP-6 and BSADP-19 respectively. Arka Cartographics Limited, Sussex, England.

Chow, V.T., Maidment, D.R. and Mays, L.W. (1988). Applied Hydrology. McGraw-Hill, New York, USA.

Cooper, H. H and Jacob, C. E. (1946). A Generalized Graphical Method for Evaluating Formation Constants and Summarizing Well-Field History. Trans. Americ. geophysical Union 27. pp 526-534.

Hazell, J. R. T., Cratchley, C. R. and Jones, C. R. C. (1992). The Hydrogeology of Crystalline Aquifers in Northern Nigeria and Geophysical Techniques used in their Exploration. Geological Society, London, Special Publications, 66, 155-182,

Matheis, G. (1989). Short Review of the Geology of the Chad Basin in Nigeria In Geology of Nigeria. In Kogbe, C. A. (Ed.), Rockview International, Jos. Nig., 341-346.

National Population Commission. (2014). Compendium of Localities in Nigeria. National Population Commission, Abuja, Nigeria.

Offodile, M.E. (2014). Hydrogeology: Groundwater Study and Development in Nigeria. Mecon Geology and Engineering Services Ltd, Jos, Nigeria.

Offodile, M.E. (2002). Groundwater Supply and Development in Nigeria. Mecon Services Ltd, Jos, Nigeria. Pp453-458.

Shemang, E.M and Jiba, K.T. (2005). Assessment of the Hydrogeologic Properties of the Basement Aquifers of Western Part of Bauchi. Global Journal of Geological Sciences Vol. 3 N.1.

Wright, E.P. and Burgess, W.G. (eds) 1992. The hydrogeology of crystalline basement aquifers in Africa. Special Publication No. 66, Geological Society, London.

United Nations Educational, Scientific and Cultural Organization (2016). World Water Development Report 2016 : Water and Jobs. Paris, UNESCO.

United Nations Environment Programme (UNEP). 2002. Global Environment Outlook 3: Past, Present and Future Perspectives. Earthscan Publications Ltd, London.

Vincent, W.U., Jaclyn A.B., William, W.D., Dennis, B.W. and Christopher C.S. (2009). Groundwater Development: Basic Concepts for Expanding CRS Water Programs. Catholic Relief Services, Baltimore, United States. Online. Available at: www.crsprogramquality.org 